\title{
Mandel $v$. Myers: Judicial Encroachment on Legislative Spending Powers
}

In Mandel v. Myers, ${ }^{1}$ the California Supreme Court considered the power of courts to compel satisfaction of money judgments rendered against the state when the state refuses to pay them. A money judginent under state law agamst the state traditionally has been held merely to liquidate the litigant's claim, while satisfaction of the judginent has been left to the legislature. The Mandel inajority decided that the legislature's refusal to satisfy Mandel's court-awarded attorney fees amounted to an unconstitutional re-adjudication of the judicial decision to award those fees, and was therefore an encroachment on judicial power. The court held that a fund appropriated for operating expenses and equipinent for the state agency that Mandel sued, though not legislatively imtended to pay the attorney fees, could by virtue of the budget's broad language be applied to the claim by judicial writ of inandate.

This Note argues that Mandel reprcsents an unconstitutional and unwise judicial usurpation of legislative control over the spending power. Although the majority purported to affirm the principle of legislative supremacy over the state purse, it circumvented that principle rather than followed it. The court einployed a dubious fiction to find an appropriation from which it could order Mandel's claim paid, although the legislative imtent was to the contrary. The case has thus imitiated a confrontation between the judiciary and the legislature, a confrontation which the legislature will mevitably win.

Part I of this Note outlines the facts of Mandel and summarizes the court's opinion. Part II sets forth the law as it existed before Mandel, and describes the scope of the legislative spending power, the judicial power to invalidate improper restrictions on budget appropriations, and the status of claims against the state. Part III contrasts this background law with the court's opimion and discusses the opinion's effect on lower courts and on the legislature. Fimally, Part IV argues that legislative supremacy over the budget is not only constitutionally mandated, but is institutionally necessary, and fair in cases like Mandel's.

1. 29 Cal. 3d 531, 629 P.2d 935, 174 Cal. Rptr. 841 (1981) (Tobriner, J.; Mosk, Newman, JJ., Reynoso, Grodin, Acting JJ., concurring; Bird, C.J., dissenting; Richardson, J., dissenting). 
I

The CASE

\section{A. The Facts}

In 1972 Shelley Mandel, an employee of the California Department of Health Services, sued to enjoin that department's practice of affording state employees three hours paid time off on Good Friday. Her suit succeeded on establishment of religion grounds, and the trial court enjoined the controller from paying state employees for time taken off on Good Friday. ${ }^{2}$ Since Mandel's efforts "resulted in a substantial benefit . . . [to] the public at large," the trial court imcluded in its judgment an attorney fee award of $\$ 25,000$ against the state. ${ }^{3}$ The court of appeal unanimously affirmed the trial court, and the California Supreme Court demied hearing. ${ }^{4}$

With final judgment in hand, Mandel sought to enforce her attorney fee award against the state, ${ }^{5}$ and submitted the $\$ 25,000$ claim to the

2. Id. at 537,629 P.2d at 938,174 Cal. Rptr. at 844 .

3. Id. The court of appeal upheld the trial court's award of attorneys' fees under the common fund doctrine (plaintiff's action resulted in the preservation of a specific fund of money from which a number of persons may benefit), and the substantial benefit rule (plaintiff's action resulted in a savings or benefit to the defendant making it fair that defendant reimburse plaintiff's attorneys' fees). See Mandel v. Hodges, 54 Cal. App. 3d 596, 620-24, 127 Cal. Rptr. 244, 260-62 (1st Dist. 1976).

This Note assumes that the attorney fee award to Mandel was appropriate under California law. CAL. Crv. Proc. CODE $\S 1021$ (West 1980) codifies the general American common law rule that attorney fees are not awarded absent either statutory or contractual provisions to the contrary. See, e.g., Fleischman Distilling Corp. v. Maier Brewing Co., 386 U.S. 714, 717-18 (1967); Arcambel v. Wiseman, 3 U.S. (3 Dall.) 306, 306 (1796) (per curiain). California has led the expansiou of attorney fee awards where equity so warrants and under inhereut judicial power. See, e.g., Serrano v. Priest, 20 Cal. 3d 25, 569 P.2d 1303, 141 Cal. Rptr. 315 (1977); CAL. Crv. Proc. Code $\S 1021.5$ (West 1980), interpreted in Woodland Hills Residents' Ass'n v. City Council, 23 Cal. 3d 917, 593 P.2d 200, 154 Cal. Rptr. 503 (1979). For a comprehensive compilation of California statutes regarding attorney fee awards, see Fishkin, Court Awards of Attorney Fees, L.A. Daily J. Rep., Jan. 22, 1982, at 3.

The importance and propriety of attorney fee awards, especially in public interest cases, have beeu extensively discussed. See, e.g., McLaughlin, The Recovery of Attorney's Fees: A New Method for Financing Legal Services, 40 ForDHAM L. REv. 761 (1972); Nussbaum, Attorney's Fees in Public Interest Litigation, 48 N.Y.U. L. Rev. 301 (1973); Note, Awarding Attomey and Expert Witness Fees in Environmental Litigation, 58 CORNELL L. REv. 1222 (1973); Note, Attorneys' Fees and the Eleventh Amendment, 88 HARv. L. REv. 1875 (1975); Note, Awarding Attorneys' Fees to the "Private Attorney General": Judicial Green Light to Private Litigation in the Public Interest, 24 Hastings L.J. 733 (1973); Comment, Court Awarded Attorney's Fees and Equal Access to the Courts, 122 U. PA. L. Rev. 636 (1974).

4. Mandel v. Hodges, 54 Cal. App. 3d 596, 127 Cal. Rptr. 244 (1st Dist. 1976). An appeal was also perfected regarding an attorney fee award for the first appeal. See Mandel v. Lackner, 92 Cal. App. 3d 747, 155 Cal. Rptr. 269 (1st Dist. 1979). The supreme court did not consider the issue of an appellate attomey fee award. $29 \mathrm{Cal}$. 3d at $538 \mathrm{n} .2,629 \mathrm{P} .2 \mathrm{~d}$ at $939 \mathrm{n} .2,174 \mathrm{Cal}$. Rptr. at 845 n.2.

5. For the law on the enforcement of judgments against the state, see CAL. Gov'T CODE $\$ \$ 965-965.9$ (West 1980) and infra text accompanying notes 50-69. See generally 45 CAL. JUR. 2D State of California \$\& 170-172 (1958). 
State Board of Control. ${ }^{6}$ Since no appropriation existed to pay Mandel's claim, the board included the sum in a claims bill introduced to the legislature in 1977. On the advice of the legislative analyst, ${ }^{7}$ the legislative committee denied an appropriation for Mandel's claim. ${ }^{8}$ Since there was no appropriation, the claim could not be paid in $1977 . .^{9}$ Mandel submitted her claim again the following year, and it was included in the budget that Governor Brown submitted for 1978-1979. Again on the advice of the legislative analyst, ${ }^{10}$ the legislature refused to appropriate for Mandel's claim. ${ }^{11}$

Having twice failed to obtain payment of her claim in the usual way, Mandel returned to the trial court and obtained an order directing that the controller pay her the $\$ 25,000$ plus interest. ${ }^{12}$ Simce no specific appropriation had been made for payment of Mandel's claim, and since the board of control had found no general appropriation otherwise available, the order directed payment to be made from funds appropriated for "[o]perating expenses and equipment" of the Department of Health Services. ${ }^{13}$ In Mandel v. Myers, the state challenged that order as violative of the separation of powers doctrine.

6. Satisfaction of judgments against the state begins with a subınission of the claim to the State Board of Control. If an appropriation exists to pay the claim, the controller draws a warrant; if no appropriation exists, the controller subinits the claim to the legislature for appropriation. Without a legislative appropriation, the claim cannot be paid. CAL. Gov'T CODE $\$ \$ 910$, 965, 965.2, 965.6 (West 1981).

7. The legislative analyst is appointed by the Joint Legislative Budget Committee to provide the committee and the legislature in general "with its own independent source of fiscal and research information. . . . The legislative analyst is requested to make specific recommendations on each item of appropriation in the Budget Bill and all special appropriation bills." J. BEEK, THE CaLIForNia Legislature 200-01 (1980).

8. 29 Cal. $3 \mathrm{~d}$ at 537,629 P.2d at 938,174 Cal. Rptr. at 844 .

9. For the requireinent of an appropriation for paying claims against the state, see infra text accompanying notes 50-69.

10. It is not important to this Note why the legislative analyst recommended against appropriating for Mandel's $\$ 25,000$ attorney fee claim, since the Note assumes the award to be correct under Califormia law. The law of California has generally been understood to permit the legislature to follow its own wisdom in passing bills, including appropriation bills. See City \& County of San Francisco v. Kuchel, 32 Cal. 2d 364, 366, 196 P.2d 545, 546 (1948); 58 CAL. JUR. 3D State of California $\$ 80$ (1980). Nonetheless, since the Mandel majority refers to the analyst's four reasons for denial, they are easily laid out: 1) Absent statute or contract, Ameriean courts do not generally award attorney fees; 2 ) it is unprecedented to award attorney fees against the state without statutory authority; 3) Mandel's attorneys' per hour charges may have been excessive; and 4) there was reason to question the number of attorneys' hours that were awarded for payinent of the claim. See 29 Cal. 3d at 538 n.1, 629 P.2d at 939 n.1, 174 Cal. Rptr. 845 at n.1.

11. 29 Cal. 3d at 538, 629 P.2d at 939, 174 Cal. Rptr. at 845.

12. Id.

13. The 1978-1979 Budget Act appropriated $\$ 37,365,036$ to the Department of Health Services for "[o]perating expenses and equipment." Budget Act of 1978, ch. 359, \& 2, item 244(b), 1978 Cal. Stat. $755,817$. 


\section{B. The Opinion}

The supreme court held that "the [trial] court order at issue in this case does not purport to compel the Legislature either to appropriate funds or to perform any other legislative act which might violate estabhished separation of powers principles." 14 The inajority ${ }^{15}$ therefore upheld the trial court's order.

The majority reached its holding through a two tier analysis. First, this situation was covered by the principle that courts can order the legislature to make a payment out of appropriated funds. While the court did not find that the operatimg expenses and equipment budget item was legislatively intended to pay Mandel's attorney fee award-given the specific refusal of the request for two years-the court did find that the budget item's "broad language . . . naturally and reasonably encompasses the payinent of attorney fees, and ... comparable budget appropriations have frequently been utilized in the past by a variety of agencies to pay similar attorney fee awards." 16 The court found the words "operating expenses and equipinent" to be so broad that money set aside for that purpose could reasonably be used to pay Mandel's award. Moreover, the court found that the prior administrative procedure was to pay awards like Mandel's out of this general appropriation. Because of the broad budget language and the prior administrative practice the court concluded that the operating expenses and equipment appropriation was available for the payment of court-awarded attorney fees agamst the Department of Health Services. ${ }^{17}$

Second, the majority reasoned that the refusal to satisfy Mandel's claim was "exphicable only as an impermissible legislative 'readjudication' of the merits of the underlying final court judginent in this case ... [and reasoned that the] separation of powers doctrine . . . precludes the Legislature from establishing itself as a 'court of last resort' to review final court judgments on a case-by-case basis . . . ."18 The court therefore viewed the failure to pay Mandel's claim from the operating expenses and equipment budget as an impermissible restriction on a valid appropriation bill. The majority drew from federal and state precedents 19 the power to invalidate "improper or invalid legislative

14. 29 Cal. 3d at 535, 629 P.2d at 937,174 Cal. Rptr. at 843 .

15. Justice Tobriner's majority opinion was joined by Justices Mosk and Newman, as well as by Acting Justices Reynoso and Grodin. Chief Justice Bird and Justice Richardson dissented in separate opinions.

16. $29 \mathrm{Cal} .3 \mathrm{~d}$ at $536,629 \mathrm{P} .2 \mathrm{~d}$ at $937,174 \mathrm{Cal}$. Rptr. at 843.

17. Id. at $542-45,629$ P.2d at $941-43,174$ Cal. Rptr. at 847-49.

18. Id. at 536, 629 P.2d at 937-38, 174 Cal. Rptr. at 843-44.

19. Shapiro v. Thompson, 394 U.S. 618 (1969); United States v. Lovett, 328 U.S. 303 (1946); State Bd. of Educ. v. Levit, 52 Cal. 2d 441, 343 P.2d 8 (1959). 
restriction $[\mathrm{s}]^{20}$ on appropriation bills. The majority held that the courts may order that Mandel's attorney fee claim be paid out of the Department of Health Services' operatimg expenses and equipment budget, since the legislature's refusal to satisfy the claim was an mvahid restriction.

The court's holding in Mandel is easily summarized: the legislature's use of broad language in appropriating funds for the Departinent of Health Services' operating expenses and equipinent inade that appropriation available to pay Mandel's attorney fee award, and the refusal to pay the claim from that budget itein, or to appropriate another itein, constituted an invalid appropriation restriction. The balance of this Note explores the California law regarding the spending power and the satisfaction of judgments against the state, and criticizes the majority's presentation of how the two interact.

II

\section{LEGAL BACKGROUND}

\section{A. The Spending Power}

California state government is sphit among executive, ${ }^{21}$ legislative, ${ }^{22}$ and judicial branches, ${ }^{23}$ with an explicit separation of powers clause $^{24}$ to prevent any branch from exercising the powers delegated to another. Among the powers delegated to the legislature is the power to spend the state's money by way of appropriation bills. ${ }^{25}$ As an effective

20. $29 \mathrm{Cal} .3 \mathrm{~d}$ at $542,546,629$ P.2d at $941,944,174 \mathrm{Cal}$. Rptr. at 847,850 . Another recent example of the supreme court's invalidation of unconstitutional legislative restrictions on appropriations is Committee to Defend Reproductive Rights v. Myers, 29 Cal. 3d 252, 625 P.2d 779, 172 Cal. Rptr. 866 (1981), discussed in Note, Committee to Defend Reproductive Rights v. Myers: Abortion Funding as an Unconstitutional Condition, 70 CALIF. L. REV. 978 (1982).

21. See Cal. Const. art. V.

22. See id. art. IV.

23. See id. art. VI.

24. "The powers of state government are legislative, executive, and judicial. Persons charged with the exercise of one power may not exercise either of the others except as permitted by this Constitution." Id. art. III, § 3. Cf. Sinking Fund Cases, 99 U.S. 700, 718 (1878) ("One branch of the Government cannot encroach on the domain of another without danger. The safety of our institutions depends in no small degree on a strict observance of this salutary rule."). But cf. Way v. Superior Court, 74 Cal. App. 3d 165, 178, 141 Cal. Rptr. 383, 392 (3d Dist. 1977) ("[e]ach branch must in soine degree exercise some of the functions of [the] others"); Levi, Some Aspects of Separation of Powers, 76 Colum. L. REv. 371, 382 (1976) (noting a tendency of one branch of government to encroach on the others to augment its power); THE FEDERALIST No. 47, at 303-07 (J. Madison) (Mentor ed. 1961) (citing exainples for the early state constitutions in violation of absolute separation of powers).

25. "Money may be drawn from the Treasury only through an appropriation made by law and upon a Controller's duly drawn warrant." CAL. CoNST. art. XVI, § 7. See Vcterans' Welfare Bd. v. Riley, 189 Cal. 159, 168, 208 P. 678, 682 (1922). The importance of the appropriations clause in the constitutional framework has long been recognized. See, e.g., J. PoMERoY, Const1TUTIONAL LAW $\$ 536$, at 348 (1870) ("The importance of this restriction [to expend treasury funds 
vehicle for keeping the "power of the purse" with the legislature, an appropriation clause analogous to California's is found in the United States Constitution, ${ }^{26}$ the Model State Constitution, ${ }^{27}$ and the state constitutions. ${ }^{28}$

A governmental appropriation is by definition a legislative act. ${ }^{29}$ It is a bill for the expenditure of the state's money, ${ }^{30}$ and in it the legislature must designate what expense of the state is to be paid, in what sum, and out of which fund. ${ }^{31}$ "In determining whether an appropriation has been made, the intention of the legislature is to be ascertained from the entire statute." 32 Legislative intent to appropriate is the only requirement usually stated for an appropriations bill. ${ }^{33}$

The separation of powers doctrine prevents courts froin interfering with legislative spending and taxing, ${ }^{34}$ with two principal exceptions.

only on an appropriation made by law] is evident. It is, indeed, the very key-stone which holds together the arch of constitutional powers and limitations. Withdraw this, and all others would become inere words, with no force of efficacy."). The legislature may not divest itself of the constitutionally guaranteed power over the budget. See California State Employees' Ass'n v. Flournoy, 32 Cal. App. 3d 219, 233-34, 108 Cal. Rptr. 251, 262 (2d Dist.), cert. denied, 414 U.S. 1093 (1973); California State Employees' Ass'n v. State, 32 Cal. App. 3d 103, 108-09, 108 Cal. Rptr. 60, 64 (3d Dist. 1973).

26. U.S. Const. art. I, $\S 9$, cl. 7.

27. Model State Const. art. VII, $\$ 7.03$ (National Mun. League 6th ed. 1963).

28. See Legislative Reference Bureau, Univ. of HawaII, Manual on State Constltutional Provisions 263 (1950); see, e.g., Colo. Const. art. V, § 33; Ga. Const. art. III, $\S 10$, cl. l; KAN. Const. art. II, § 24; MD. Const. art. III, § 32; NEB. Const. art. III, § 25; N.Y. ConsT. art. VII, § 7; N.D. CoNST. art. X, § 12, cl. 1; OKLA. CoNST. art. V, § 55; OR. ConsT. art. IX, § 4; PA. Const. art. III, $\S 24 ;$ TEX. CONST. art. XIII, $\S 6$. Since the various state clanses and the federal clanse are so similar to the California clause, analyses from jurisdictions other than California inay be helpful in understanding the California clause.

29. Black's Law Dictionary 93 (rev. 5th ed. 1979).

30. See Stratton v. Green, 45 Cal. 149, 151 (1872); CAL. Const. art. IV, § 12.

31. Humbert v. Dunn, 84 Cal. 57, 59, 24 P. 111, 111-12 (1890). See also Stratton v. Green, 45 Cal. 149, 151 (1872); Ryan v. Riley, 65 Cal. App. 181, 187, 223 P. 1027, 1029 (3d Dist. 1924) (neither purpose nor amount inay be uncertain or indefinite).

32. Riley v. Johnson, 219 Cal. 513, 519, 27 P.2d 760, 762 (1933) (per curiam). Cf. Darnall v. State, 79 S.D. 59, 65-66, 108 N.W.2d 201, 204 (1961) (appropriations for jnst compensation in eminent domain proceedings are self-executing). In 1980, CAL. CIv. Proc. CodE $\$ 1268.020$ (West Supp. 1982) was amended to make clear that eminent doinain judgments are not enforceable against a public entity by execution or other remedies provided for a judgment creditor under the California Code of Civil Procedure. See Act of June 20, 1980, ch. 215, \& 1, 1980 Cal. Stat. 449, 449; Recommendation Relating to Enforcement of Claims and Judgments Against Public Entities, 15 CAL. L. Revision COMM'N REP. 1257, 1268-69 (1980).

33. See, e.g., Mason-Walsl-Atkinson-Kier Co. v. Department of Labor \& Indus., 5 Wash. 2d 508, 514-15, 105 P.2d 832, 836 (1940); Irons v. Harrison, 185 Ga. 244, 249, 194 S.E. 749, 753 (1937); Riley v. Carter, 165 Okla. 262, 268, 25 P.2d 666, 672 (1933).

34. The fact that the speuding and taxing powers may be involved in a case does not bar judicial consideration of the issues over which the courts do have jurisdiction. See, e.g., Helvering v. Davis, 301 U.S. 619, 640-41 (1937); United States v. Butler, 297 U.S. 1, 62-78 (1936); Veazie Bank v. Fenno, 75 U.S. (8 Wall.) 533, 541 (1869); Weeks v. United States, 406 F. Supp. 1309, 1328 (W.D. Okla. 1975); California State Employees' Ass'n v. Cory, 123 Cal. App. 3d 888, 896, 176 Cal. Rptr. 904, 909 (3d Dist. 1981). 
The first and most dramatic example of judicial spending involves the care of the institutionalized mentally ill, juveniles, and prisoners. ${ }^{35}$ The second type of judicial spending is less controversial, perhaps because the judiciary has asserted its power in this area for decades. It encompasses the right of the judiciary to command its own budget and to compel the government to pay its reasonable expenses in its administration of justice. ${ }^{36}$. These two areas comprise the most significant judicial exercise of what is otherwise an exclusively legislative power.

\section{B. Judicial Invalidation of Improper Restrictions on Appropriations}

The Mandel majority in large part based its decision on the judicial power to invalidate improper restrictions on appropriations, ${ }^{37}$ as stated in State Board of Education v. Levit ${ }^{38}$ and United States $v$. Lovett. ${ }^{39}$ Levit and Lovett stand for the principle that "once funds have already been appropriated by legislative action, a court transgresses no constitutional principle when it orders the State Controller or other similar official to make appropriate expenditures from such funds."40

Levit arose out of a clause in the California Constitution that gave the State Board of Education the exclusive power to choose the textbooks for use im the state school system. ${ }^{41}$ In the Budget Act of 1958,

35. See generally Frug, The Judicial Power of the Purse, 126 U. PA. L. Rev. 715 (1978). A court will usually not order the direct appropriation of funds for the correction of an unconstitutional practice, but will merely enjom it. See, e.g., Jordan v. Wolke, 593 F.2d 772, 775 (7th Cir. 1978) (per curiam), appeal after remand, 615 F.2d 749 (7th Cir. 1980). Some courts have held that they enjoy the power to block the legislature from retroactively rescinding an appropriation and from emptying an appropriation to prevent collection by a claimant. See People ex rel. McCauley \& Tevis v. Brooks, 16 Cal. 11, 34 (1860); National Ass'n of Regional Councils v. Costle, 564 F.2d 583, 589 (D.C. Cir. 1977).

36. See, e.g., Ex parte United States, $101 \mathrm{~F} .2 \mathrm{~d} 870,878$ (7th Cir.), affd sub nom. United States v. Stone, 308 U.S. 519 (1939) (per curiam); Commonwealth ex rel. Carroll v. Tate, $442 \mathrm{~Pa}$. 45, 52-55, 274 A.2d 193, 197-99, cert. denied, 402 U.S. 974 (1971); Young v. Board of County Comm'rs, 91 Nev. 52, 55-56, 530 P.2d 1203, 1206 (1975). The power of courts to compel payment of their reasonable expenses has been dealt with in detail. See generally Brennan, Judicial Fiscal Independence, 23 U. FLA. L. Rav. 277 (1971); Comment, State Court Assertion of Power to Determine and Demand Its Own Budget, 120 U. PA. L. Rev. 1187 (1972). What expenses are reasonable, and therefore fall within the court's power, remains a hard question and has led to contradictory holdings. Compare Luke v. County of Los Angeles, 269 Cal. App. 2d 495, 497, 74 Cal. Rptr. 771, 772-73 (2d Dist. 1969) with County of Fresno v. Superior Court, 82 Cal. App. 3d 191, 195-96, 146 Cal. Rptr. 880, 881-82 (5th Dist. 1978). Compare also, e.g., Jackson v. State, 413 P.2d 488 (Alaska 1960) with, e.g., State v. Rush, 46 N.J. 399, 217 A.2d 441 (1966).

37. $29 \mathrm{Cal}$ 3d at 539-42, 629 P.2d at 939-41, 174 Cal. Rptr. at 845-47.

38. 52 Cal. 2d 441, 343 P.2d 8 (1959).

39. 328 U.S. 303 (1946).

40. 29 Cal. 3d at 540,629 P.2d at 940, 174 Cal. Rptr. at 846. See also Califano v. Goldfarb, 430 U.S. 199, 204-24 (1977); Memorial Hosp. v. Maricopa County, 415 U.S. 250, 253-70 (1974); Shapiro v. Thompson, 394 U.S. 618, 627 (1969). See generally Willcox, Invasions of the First Amendment Through Conditioned Public Spending, 41 CoRnelu L. Rev. 12, 36-37 (1955).

41. In 1959, when Levit was decided, the State Board of Education enjoyed the power to "provide, coinpile, or cause to be compiled, and adopt a uniform series of textbooks for use in the 
the legislature appropriated money for the acquisition of textbooks, but with the express restriction that "[n]one of the moneys appropriated ... shall be expended for publishing, purcliasing, shipping, or paying royalties for the books known as 'Science for Work and Play' and 'Science for Here and Now." "42 The legislature thereby attempted to circumvent the Board of Education's constitutional power to clioose school textbooks. In spite of the restriction, the Board of Education selected "Science for Work and Play" and "Science for Here and Now," and then sued the director of finance to pay on the contract. The California Supreine Court leld that the appropriation restriction was an unconstitutional restriction on the board's exclusive power to select textbooks, and the court ordercd the payment of the contract. ${ }^{43}$ Although the legislature had no constitutional obligation to appropriate money for textbooks, the court stressed that once the legislature did appropriate funds to purchase texts, courts could properly strike down any restriction that the legislature might place on the board's exclusive power to select textbooks. Therefore, the courts could compel the legislature to spend the appropriated funds without regard to the unlawful restriction. ${ }^{44}$

Lovett arose out of a challenge to the constitutionality of section 304 of the Urgent Deficiency Appropriations Act of $1943 .{ }^{45}$ In pertinent part, Section 304 provided that "[n]o part of any appropriation . . . shall be used . . . to pay any part of the salary, or other compensation for the personal services, of Goodwin B. Watson, William E. Dodd, Jumior and Robert Morss Lovett . . . ."46 The inotivation for the section was that these three people had been found "guilty of liaving engaged in 'subversive activity . . . ." "47 The Court held that section 304 violated the constitutional prohibitions agamst bills of attainder and ex post facto laws. ${ }^{48}$ The Court therefore struck down the restriction as unlawful and held that section 304 "does not stand as an obstacle to the payment of compensation to Lovett, Watson and Dodd." 49

Levit and Lovett stand for the saine rule of constitutional law: when the legislature chooses to appropriate funds for a given purpose,

.. . elementary schools throughout the State" under CAL. Const. art. IX, \& 7. On June 2, 1970, CAL. ConsT. art. IX, § 7.5 replaced the old $\S 7$.

42. Act of May 24, 1958, ch. 1, § 2.2, item 435, 1958 Cal. Stat., $2 d$ Extra Sess., 465, 557-58.

43. $52 \mathrm{Cal} .2 \mathrm{~d}$ at $465-66,343$ P.2d at 22 .

44. Id.

45. The aet was "urgent" because the appropriated momes were needed to fund continued American involvement in World War II. 328 U.S. at 305 n.1.

46. Id.

47. Id. at 311.

48. Id. at 315-16.

49. Id. at 318 . 
such as purchasing textbooks or paying salaries, it may not constitutionally exclude a class that falls within the appropriation. To violate the rule of Levit and Lovett, however, the legislature must make both a valid appropriation and an unconstitutional restriction on that appropriation.

\section{Claims Against the State}

States are organized under constitutions which lay the states' spending powers in legislative hands. ${ }^{50}$ As a result of legislative control over the purse, many states already have confronted the central issue in Mandel: what happens when the judiciary declares the state to be a debtor in a final judgment, and the state refuses to pay? The vast majority of state courts, including California, have held that the creditor must await payment from the legislature, because ordering payment without appropriation is beyond judicial power. Thus, a judgment against the state is usually just a liquidated claim, and the claimant is not paid until the legislature sees fit to pass an appropriation.

Most courts resolved this particular judicial-legislative spending power conflict early, with the judiciary accepting legislative supremacy over the purse in order to avoid a constitutional conflict. For example, in 1893 the Colorado Supreine Court held that "[n]o matter . . . how just or equitable petitioners' claim may be, no duty can devolve upon the auditor to issue his warrant for the payinent of such claim until appropriation shall be made by law for that purpose."51 Where costs have been charged properly against the state $\mathrm{m}$ judicial proceedimgs, ${ }^{52}$ and where taxpayers have sued for and won recovery of taxes collected under protest, ${ }^{53}$ courts have demied the power and authority to compel payment when no specific appropriation for the purpose existed. Judicially declared creditors of a state are generally admonished that their claims are "adjustable only by the Legislature," 54 which means they should pursue whatever pohtical renedy may be available in the legis-

50. See supra note 28.

51. Collier \& Cleveland Lithographing Co. v. Henderson, 18 Colo. 259, 263, 32 P. 417, 418 (1893); accord Herrick v. Gallet, 35 Idaho 13, 17-18, 204 P. 477, 478 (1922); Panhandle E. Pipeline Co. v. Fadely, 189 Kan. 283, 286, 369 P.2d 356, 359 (1962); State ex rel. Hudson v. Carter, 167 Okla. 32, 37, 27 P.2d 617, 621 (1933).

52. See Texas Dep't of Pub. Safety v. Morris, 426 S.W.2d 290, 294 (Tex. Civ. App.), rev'd on other grounds, 436 S.W.2d 124 (Tex. 1968).

53. See, e.g., People ex rel. Bankers' Trust Co. v. Graves, 152 Misc. 531, 535, 274 N.Y.S. 260, 265-66 (1934), affd per curiam, 245 A.D. 166, 281 N.Y.S. 312 (1935), affd, 270 N.Y. 316, 321, 1 N.E.2d 114, 116 (1936) ("The state is not liable unless it provides for its liability.").

54. Sigwald v. State, 50 S.D. 37, 38-39, 208 N.W. 162, 163 (1926); accord Griffis v. State, 69 S.D. 439, 445, 11 N.W.2d 138, 139 (1943); Pietz v. State, 65 S.D. 52, 53-54, 270 N.W. 648, 648-49 (1936). 
lature in order to effectuate an appropriation for the claim. ${ }^{55}$

California courts always have been in harmony with this judicial deference to the legislature's power to pay judgments against the state. The early case of Myers $\nu$. English ${ }^{56}$ declared the legislature supreme in budget matters, and eloquently stated a claimant's pohtical remedies. ${ }^{57}$ The supreme court affirmed English in Westinghouse Electric Manufacturing Co. v. Chambers, ${ }^{58}$ the first modern California case to recognize the right of the legislature to decide when and how to pay a judgment or claim. Westinghouse had paid $\$ 2,700$ in tax to the state under protest and sued for a refund of the tax. When Westinghouse prevailed, the final judgment fixed its claim. ${ }^{59}$ Westinghouse then sought to enforce its claim and sued for a writ inandating the issuance of a state warrant for payment. Although there was a statute permitting judicial declaration of the rights of the parties, the supreme court found that no appropriation existed for the repayment of the unlawfully collected taxes. The court was therefore powerless to issue a writ. ${ }^{60}$ In a unanimous opimion, the court said:

The general rule is well established that a judgment against the state ... merely liquidates and establishes the claim against the state, and that, in the absence of an express statute so providing, such judgment cannot be collected by execution against the state or its property . . . . [I]t remains for the state, after such judgment, to provide for the payment thereof in such manner as it sees fit, or to refuse to do so at its pleasure ....61

55. Before instituting ler action for mandamus, Mandel pursued the political remedy by lobbying the legislature to appropriate for ler claim. See $29 \mathrm{Cal}$. 3d at 537-38,629 P.2d at 938, 174 Cal. Rptr. at 844.

56. 9 Cal. 341 (1858).

57. It is very true that the Legislature possesses the power to stop the whole machinery of government, whenever it is willing to take the responsibility of doing so. . . The Legislature has the power to repeal all existing revenue laws, and thus leave the State treasury without funds.

... We think the power to collect and appropriate the revenue of the State is one peculiarly within the discretion of the Legislature. It is a very dehcate and responsible trust, and if not used properly by the Legislature at one session, the people will be certain to send to the next more discreet and faithful servants.

It is within the legitimate power of the judiciary to declare the action of the Legislature unconstitutional, where that action exceeds the limits of the supreme law; but the Courts have no means, and no power, to avoid the effects of non-action. . . . Therefore, when the Legislature fails to make an appropriation, we cannot remedy that evil. . . . We must trust to the good faith and integrity of all the departments. Power must be placed somewhere, and confidence reposed in some one.

Id. at 349.

58. 169 Cal. 131, 145 P. 1025 (1915).

59. Id. at $135,145 \mathrm{P}$. at 1026 .

60. Id at $142-43,145$ P. at 1029 .

61. Id. at 135, 145 P. at 1026; accord People v. San Joaquin Valley Agricultural Ass'n, 151

Cal. 797, 806, 91 P. 740, 744 (1907); Smith v. Broderick, 107 Cal. 644, 650, 40 P. 1033, 1035-36 (1895).

Federal law is in accord with most states in holding that a judicially declared debt is not 
The rule concerning the legislature's exclusive power to pay judgments against the state has been affirmed regularly by the California courts, ${ }^{62}$ and has been codified by the California Legislature. ${ }^{63}$ California administrative agencies have adopted procedures that also reflect this rule of exclusive legislative power. ${ }^{64}$ The administrative procedures for the satisfaction of claims and judgments against the State of California begims when a judginent holder submits a claim to the State Board of Control. ${ }^{65}$ If there is a sufficient appropriation to pay the

payable until appropriated for by an act of the appropriate legislature. Claimants must rely on the good faith of the Umited States to pay its claims, smce absent an appropriation by Congrcss, the claims cannot be paid. See, e.g., Regional Rail Reorganization Act Cases, 419 U.S. 102, 149 n.35 (1974); Glidden Co. v. Zdanok, 370 U.S. 530, 571 (1962); see also 28 U.S.C. \$§ 2414, 2517 (1976 \& Supp. III 1979 \& West Supp. 1982) (payment of judgment against the Umited States requires congressional appropriation); 2 J. STORY, COMMENTARIES ON THE CONSTITUTION OF THE UNITED STATEs 222-23 (M. Bigelow 5th ed. 1891) (before payment can be made, government debts must pass in review before Congress). The law of execution is therefore not available against public entities. See, e.g., Railroad Co. v. Tennessee, 101 U.S. (11 Otto) 337, 339-40 (1879); 3 Op. Att'y Gen. 1, 13 (1835); 2 Op. Att'y Gen. 663, 670 (1834). See generally 2 A. Freeman, The LAW of EXECUTIONS $\$ 172$, at $885-86$ ( $3 \mathrm{~d}$ ed. 1900 ).

62. See, e.g., Tevis v. City \& County of San Francisco, 43 Cal. 2d 190, 200, 272 P.2d 757, 763 (1954); Polk v. State, 138 Cal. 384, 388, 71 P. 435, 436 (1903); Hunsaker v. Borden, 5 Cal. 288, 290 (1855); Harland v. State, 99 Cal. App. 3d 839, 847, 160 Cal. Rptr. 613, 617-18 (1st Dist. 1979); Veterans of Foreign Wars v. State, $36 \mathrm{Cal}$. App. 3d 688, 697, $111 \mathrm{Cal}$. Rptr. 750, 756 (3d Dist. 1974); California State Employees' Ass'n v. State, 32 Cal. App. 3d 103, 109-10, 108 Cal. Rptr. 60, 63-64 (3d Dist. 1973).

63. See CAL. Gov'T CODE $\$ \$ 965.2$ (warrant to be drawn only when appropriation exists), 965.5(b) (judgments against state not enforceable under the CAL. CIV. Proc. CodE \$\$ 681-723 (West 1980 \& Supp. 1982)), 965.6 (no claim or judgment paid unless specifically authorized by legislature or the dircctor of finance lias certified the existence of an appropriation), 965.7 (no mandate may affect legislative discretion to appropriate or to pay judgments) (West 1980). Pursuant to CAL. Gov'T CODE $\$ 965.8$ (West 1980), a writ of mandate may lie only to compel the ministerial act of ascertaining whether an appropriation exists. Without that appropriation, no claim or judgment may be paid. See Flora Crane Serv., Inc. v. Ross, 61 Cal. 2d 199, 208-09, 390 P.2d 193, 199, 37 Cal. Rptr. 425, 431 (1964); Fowler v. Pierce, 2 Cal. 165, 167 (1852); Straughter v. State, 108 Cal. App. 3d 412, 416, 169 Cal. Rptr. 471, 473 (3d Dist. 1980).

The legislature's understanding is that it cannot be judicially mandated to pay claims:

Payment [of claims and judgments] can be coinpelled only where there is a sufficient appropriation for the payment of the claim, settlement, compromise, or judgment . . . . The traditional forms of enforcement of a money judgment (execution and other remedies under the Code of Civil Procedure) are not available to enforce a judgment against the state or a state agency. ... .

[CAL. GOV'T CODE \& 965.7(b)] is included to make clear that a writ of mandate may not be used to compel the Legislature to inake an appropriation or to authorize a payment or offset. This codifies existing law [citing Myers v. English, see supra note 56; Veterans of Foreign Wars v. State, see supra note 62; California State Employees' Ass'n v. State, see supra note 62].

Recommendation Relating to Enforcement of Claims and Judgments Against Public Entities, $14 \mathrm{CAL}$. L. Revision CoMM'N Rep. 1257, 1278 (1980). Cf. War Brewing? Legislators Balk at Court-Ordered Attorneys' Fees, L.A. Daily J., June 22, 1981, at 1, col. 6 (State Senate Republican Leader William Campbell: "If [the state supreme court justices] want to legislate, let them run for the legislature. To disburse funds of the State of California is not a judicial responsibility.").

64. See generally Recommendation Relating to Enforcement of Claims Against Public Entities,

14 CAL. L. REVISION COMM'N REP. 157 (1980).

65. See CAL. Gov'T CodE $\$ \$ 910-915.4,965$ (West 1980). 
claim, the board designates the fund from which the claim is to be paid, and the appropriate state agency pays the claim from the designated fund. ${ }^{66}$ If the judgment holder submits the clami to the board, and it is determined that no appropriation exists to cover it, the board reports the deficiency to the legislature so that it may consider appropriatimg for the claim. ${ }^{67}$ Appropriations are not interchangeable, and each can be used only for the particular purpose defined in the act making the appropriation. ${ }^{68}$ Without the legislative appropriation, the claim cannot be paid by the board or any agency. ${ }^{69}$

III

ANALYSIS

\section{A. The Fictitious Appropriation}

The majority analyzed Mandel as an unlawful restriction on appropriations case. As required by this doctrine, the court employed the two tier analysis set out above. ${ }^{70}$ First, the court found that an appropriation to cover Mandel's claim did im fact exist. The court then concluded that the legislature's refusal to satisfy Mandel's claim was an unconstitutional restriction, which the court imvalidated. The majority erred, however, im the first tier of its analysis. The legislature never appropriated money to pay attorney fee claims like Mandel's. The court therefore should never have reached the second tier of analysis.

The legislature expressly refused to appropriate money to pay Mandel's claim. Simce the majority recognized this fact, ${ }^{71}$ it relied on the argument that the legislature's language in appropriatimg for the Department of Health Services" "operating expenses and equipinent" was so broad that Mandel's claim conld be brought within its wording. This reasoning has two serious flaws.

The first flaw concerns the court's misuse of legislative history. Appropriations bills, like all other bills, must be construed in light of legislative intent. ${ }^{72}$ The legislative history of the 1978-1979 Budget Act

66. See id. $\S \S 965,965.2$.

67. See id. $\S \S 965,912.8,13914$.

68. See Cal. Admin. Code tit. $2, \& 613$ (1981).

69. See CaL. Gov'T CODE $\$ 965.6$ (West 1980).

70. See supra text accompanying notes 16-20; cf. supra text accompanying notes 37-49 (applications of this doctrine in the Levit and Lovett cases).

71. See $29 \mathrm{Cal} .3 \mathrm{~d}$ at 552, 629 P.2d at 948, $174 \mathrm{Cal}$. Rptr. at 854, see also id. at 555, 629 P.2d at 950, 174 Cal. Rptr. at 856 (Ricliardson, J., dissenting); id. at 559, 629 P.2d at 952, 174 Cal. Rptr. at 858 (Bird, C.J., dissenting).

72. See, e.g., People v. Ruster, 16 Cal. 3d 690, 696, 548 P.2d 353, 356, 129 Cal. Rptr. 153, 156 (1976); Van Nuis v. Los Angeles Soap Co., 36 Cal. App. 3d 222, 228, 111 Cal. Rptr. 398, 402 (2d Dist. 1973); CaL. Crv. Proc. Code $\$ 1859$ (West 1955). See generally Frankfurter, Some Reflections on the Reading of Statutes, 47 Colum. L. REv. 527, 533-38 (1947). 
reveals that no appropriation in this budget could be used to pay Mandel's claim. The same year that the legislature passed the 19781979 Budget Act, including item 244(b) allotting over $\$ 37$ million to the Department of Health Services for operating expenses and equipment, the legislature expressly refused to appropriate for Mandel's claim. When the legislature passes one section of an act (such as the operating expenses and equipment budget itein), but expressly refuses to pass another section (such as the item for Mandel's attorney fee award), the legislature cannot be said to have included the refused section within the approved section. In deciding that the legislature had appropriated money for a budget item that the legislature had expressly refused to fund, the court in Mandel imaugurated a form of judicial construction that cannot be squared with prior law.

The second flaw concerns the court's reliance on several cases that supposedly show that the standard operating procedure in the Department of Health Services is to pay attorney fee awards out of the agency's operating expenses and equipment budget. ${ }^{73}$ The cases cited, however, do not stand for this proposition. Five of the six cases involved funds other than the Department of Health Services' operating expenses and equipment fund. The administrative practice regarding appropriations for operating expenses and equipment and for general expenses in departments other than the Department of Health Services is not relevant in determining Health Services' standard practices. The practices of other departments simply do not establish the practices of Health Services.

One of the six cases, Steilberg $v$. Lackner,${ }^{74}$ did involve the Health Services' operating expenses and equipment budget, but it did not involve a Mandel-type attorney fee award. Steilberg involved a woman who applied for Medi-Cal ${ }^{75}$ benefits as a "[m]edically indigent person."76 The welfare director denied her benefits and Steilberg sought judicial review, invoking special provisions that the legislature passed to ease the financial burden on Californians who must turn to the courts to vindicate their welfare rights. The neasures include waiving court filing fees and bond posting on appeal, as well as the mandatory award of reasonable attorney fees if the claimant prevails in reversing the welfare director's decision. ${ }^{77}$ Therefore, when Steilberg won a re-

73. See 29 Cal. 3d at 544 n.5, 629 P.2d at 942 n.5, 174 Cal. Rptr. at 848 n.5.

74. 69 Cal. App. 3d 780, 138 Cal. Rptr. 378 (1st Dist. 1977).

75. Medi-Cal is the California state health care public assistance program established by CAL. WeLF. \& INST. CODE $\S 14000$ (West 1980).

76. See id. $\$ 14051$ (West Supp. 1982).

77. See id. $\S 10962$. The measure was enacted to help the needy vindicate their welfare rights. See, e.g., Silberman v. Swoap, 50 Cal. App. 3d 568, 571, 123 Cal. Rptr. 456, 458 (4th Dist. 1975); Trout v. Carleson, 37 Cal App. 3d 337, 343, 112 Cal. Rptr. 282, 286 (4th Dist. 1974). 
versal, her claim fell within the express legislative award of attorney fees in welfare cases. ${ }^{78}$ Because the attorney fee award in Steilberg was not just legislatively intended but was legislatively mandated; Steilberg provides little, if any, support for the proposition advanced by the Mandel court.

Moreover, the award in Steilberg was trivial compared to Mandel's. ${ }^{79}$ One payment to Steilberg of just over $\$ 3,500$ froin the operating expenses and equipment budget for a legislatively mandated attorney fee award does not establish a precedent for a $\$ 25,000$ payment from the same fund for Mandel's lcgislatively refused award. The payment to Steilberg inay have been erroneously cliarged to the operating expenses and equipment budget, ${ }^{80}$ or the board of control may have considered it to be too sinall to submit to the legislature for separate appropriation. It is not clear why Steilberg was paid out of operating expenses and equipment, and the Mandel majority was stretching when it extrapolated a general administrative procedure from the sparse record. If the Health Services procedure for paying Mandel-type attorney fee awards was to pay thein out of operating expenses and equipment, then Mandel would have been paid in 1977, when the board of control refused ler claim for lack of an appropriation. ${ }^{81}$ It was precisely because the board did not view Mandel's claim as payable out of operating expenses and equipinent that the board of control submitted the claim to the legislature, ${ }^{82}$ which then explicitly refused to appropriate for it.

Since the legislature never passed an appropriation to pay Mandel's claim, the court should never have reached the second tier of its analysis, and hence should never have invoked the doctrine against improper restrictions set forth in Levit and Lovett. ${ }^{83}$ In both Levit and Lovett, an appropriation existed for the type of expenses that were ordered to be paid. In Levit, the legislature had appropriated funds for the purchase of textbooks and the court ordered that textbooks be

78. 60 Cal. App. $3 d$ at 789, 138 Cal. Rptr. at 384.

79. Steilberg apparently received an award of $\$ 3,854.78$. See 29 Cal. $3 d$ at 544 n.5, 629 P.2d at 942 n.5, 174 Cal. Rptr. at 848 n.5.

80. The majority summarily dismissed the possibility of an erroneous charge to the operating expenses and equipment budget item. See id. at 544, 629 P.2d at 943, 174 Cal. Rptr. at 849.

81. See CAL. Gov't CoDE $\$ \S 965,965.2$ (West 1980).

82. The Mandel majority appeared confused as to the administrative procedure for paying Mandel's claim. The source of the problem may lie in the fact that there was no firmly established procedure for paying Mandel-type attorney fee awards because sucl awards were rare at the time. When the board of control received Mandel's claim it may have had no clear procedure for paying such a claim, so it referred the claim to the legislature for appropriation. Although there is no clear history available which details the handling of Mandel's claim, nothing indicates that Mandel's claim was processed under any procedures whicls were not ordinary and appropriate.

83. See supra text accompanying notes $37-49$. 
purchased. In Lovett, the legislature had appropriated funds for the payment of salaries and the Court ordered that salaries be paid. But in Mandel, the legislature never inade an appropriation to pay Mandel's claim, or any attorney fee award like Mandel's. Therefore, the court's rehance on Levit and Lovett was misplaced.

It is noteworthy that Levit based its finding of unconstitutionality on an express constitutional provision that the legislature had no power to do what it was atteinpting. ${ }^{84}$ Similarly, Lovett based its finding of unconstitutionality on the express constitutional prohibitions against bills of attainder and ex post facto laws. ${ }^{85}$ Thus, both Levit and Lovett declared a particular legislative action to be unconstitutional. In Mandel, however, the court focused on legislative inaction-its failure to appropriate for the payinent of Mandel's clamı-and declared that such inaction could not be used to restrict an appropriation for operating expenses and equipinent. Since there is no constitutional prohibition against such legislative inaction, the Mandel court should not have rehed on Levit and Lovett.

Moreover, Levit and Lovett counsel against an evil not present in Mandel. Those two cases would have controlled in Mandel if the legislature had appropriated funds for the payment of court-awarded attorney fees for successful plaintiffs against the state and then restricted the appropriation with a proviso in the form: "Provided, none of these funds shall be used to pay Shelley Mandel's attorney fee award." This was not the type of legislative act at issue in Mandel. Rather, the legislature refused to appropriate any inoney at all for attorney fee awards. Both Levit $^{86}$ and Lovett ${ }^{87}$ are distinguishable froin Mandel because they recognized the legislature's right to appropriate nothing at all. They held only that given an appropriation, it inust be constitutional.

Although the Mandel inajority steadfastly maintained that "the court order at issue in this case does not purport to compel the Legislature either to appropriate funds or to perform any other legislative act," ${ }^{88}$ the effect of the order was exactly that. Simce no appropriation existed which was intended to pay Mandel's award, the court's order was necessarily directed at an appropriation which was not intended to pay the award. Judicial expansion of an appropriation beyond its legislatively intended scope, as a practical matter, anounts to judicial appropriation. In effect, the court ordered funds to be appropriated so

84. See 52 Cal. $2 \mathrm{~d}$ at $465-66,343$ P.2d at 22 .

85. See 328 U.S. at 315-16.

86. 52 Cal. $2 \mathrm{~d}$ at $465-66,343$ P.2d at 22.

87. 328 U.S. at 313 .

88. 29 Cal. 3d at 535, 629 P.2d at 937,174 Cal. Rptr. at 843 ; see also id. at $551-52,629$ P.2d at 947, 174 Cal. Rptr. at 853. 
that Mandel's claim could be paid. Such an order transgresses the constitutional principle that the legislature alone controls state funds.

\section{B. Mandel's Effect}

Mandel stands for the proposition that courts may order the payment of judicially declared claims against the state, even though the legislature has refused to appropriate for the claims, where there is language in the budget act broad enough to cover the type of claim involved. This will be difficult precedent for lower courts to follow. The Mandel majority, although claiming to follow prior law, actually went beyond and contrary to precedent. Lower courts thus will be challenged to reconcile Mandel with the authority it cites. Mandel's effect on the legislature is also troublesome, because it pushes the legislature one step further in the direction of completely ignoring state court orders.

\section{The Effect on Lower Courts}

After Mandel, Myers v. English ${ }^{89}$ and Westinghouse Electric Co. v. Chambers ${ }^{90}$ are in a state of stare decisis limbo. Mandel read those cases very narrowly, as holding only that the courts may not compel the legislature to pass a specific piece of legislation. ${ }^{91}$ Since $M a n d e l$ purported not to compel the legislature to enact any legislation "or to perform any other legislative act,",92 it claimed to fall witlim both English and Westinghouse. ${ }^{93}$ By relying on those two cases, the court affirmed their authority in Califorma. Yet a few sentences after this implicit affirmation of English and Westinghouse, Mandel explicitly disapproved them to the extent that they permit legislative discretion in paying money judgments against the state. ${ }^{94}$ Thus the majority was in the peculiar position of partially overruling cases that it relied on for support.

Although Mandel professed to rely on English and Westinghouse, it in fact ran afoul of the primciple of those cases. Both cases expressly recognized the legislature's discretion to appropriate for the payinent of money judgments against the state. ${ }^{95}$ Since Mandel denied such legislative discretion, it emasculated the English and Westinghouse hold-

89. 9 Cal. 341 (1858).

90. 169 Cal. 131, 145 P. 1025 (1915).

91. $29 \mathrm{Cal} .3 \mathrm{~d}$ at $551 \mathrm{n} .9,629$ P.2d at $947 \mathrm{n} .9,174 \mathrm{Cal}$. Rptr. at 853 n.9.

92. Id. at 535,629 P.2d at 937,174 Cal. Rptr. at 843.

93. See id. at $551 \mathrm{n} .9,629 \mathrm{P} .2 \mathrm{~d}$ at $947 \mathrm{n} .9,174 \mathrm{Cal}$. Rptr. at $853 \mathrm{n} .9$.

94. "To the extent that language in Myers and Westinghouse can be read to suggest that the Legislature is not constrained by the separation of powers doctrine in exercising its appropriations powers, such language conflicts with Levit and Lovett and inust be disapproved." Id.

95. See Westinghouse, $169 \mathrm{Cal}$ at 135, 145 P. at 1026; English, 9 Cal. at 349. 
ings. This equivocal handling of English and Westinghouse will leave lower courts uncertain about how inuch precedential weight to accord these two cases. More important, Mandel's obfuscation of the legal principle involved leaves lower courts with no clear guide as to how inuch discretion the legislature may exercise in appropriating funds for inoney judgments against the state.

Appellate court cases since Mandel have shown an understandable uncertainty as to how to follow the supreine court's lead in going beyond legislative intent in construing appropriations. In cases seemingly controlled by Mandel, lower courts have declined to order state payments where there has been no legislative intent to permit payınent. For example, Committee to Defend Reproductive Rights v. Cory $(C D R R)^{96}$ cited Mandel as authority for the proposition that after the supreme court has struck down an unlawful restriction on an appropriation, courts inay order the state to pay those expenses that reasonably fall within the language of the appropriation, without considering the unlawful restriction. ${ }^{97}$ The court of appeal in $C D R R$, however, did not strike down the express restriction on court-awarded attorney fees that was written into the 1981 Budget Act, ${ }^{98}$ and therefore declined to order the award of attorney fees. The court in $C D R R$ thereby avoided a challenge to the legislative choice not to appropriate for attorney fees, even though the $C D R R$ suit, like the Mandel suit, was against the Department of Health Services. Hence the court of appeal in CDRR refused to follow the supreine court's precedent in Mandel, even though the facts of these two cases were very similar. If it had followed Mandel, the court in $C D R R$ would have struck down the restriction and ordered the payment of attorney fees froin the department's operating expenses and equipinent budget. Instead, the $C D R R$ court deferred to the legislative intent not to pay the attorney fees. This refusal to follow Mandel suggests that either lower courts are uncertain of how to apply Mandel, or they perceive Mandel as an anoinaly to be distinguished whenever possible.

96. 125 Cal. App. 3d 341, 178 Cal. Rptr. 62 (1st Dist. 1981).

97. See id. at 346, 178 Cal. Rptr. at 66.

98. See id. at 347, 178 Cal. Rptr. at 66. Budget Act of 1981, ch. 99, § 4.50, 1981 Cal. Stat. - states:

No funds appropriated by this act may be used to pay court-awarded attorney's fees unless payment of such fees is either: (a) Specifically authorized and set forth in an item or section of this act; or (b) Expressly authorized by a statutory provision other than Section 1021.5 of the Code of Civil Procedure. Provided that this section shall not be construed as making an appropriation of funds for the payment of court-awarded attorney's fees.

The legislature included a general restriction in the 1978 Budget Act to the effect that the Act should be construed in the light of legislative intent. See Budget Act of 1978, ch. 359, \& 15, 1978 Cal. Stat. 761, 1006. Judicial disregard of that admonishment may have been the inotive for including the more specific $\$ 4.50$ in the 1981 Budget Act. 
In California State Employees' Association v. Cory (CSEA), ${ }^{99}$ another court of appeal declined to follow Mandel's lead. CSEA discussed $M a n d e l$, but refused to order the state to pay prejudginent interest where the legislative intent to pay the interest was not apparent. ${ }^{100} \mathrm{Al}-$ though the CSEA court concluded that the petitioners were legally entitled to the interest, payment of the interest had to await legislative appropriation. ${ }^{101}$ Like the court in $C D R R$, the court in $C S E A$ deferred to the legislature's discretion to appropriate for money judgments agaimst the state. While CSEA is correct under pre-Mandel law, it, like $C D R R$, does not heed Mandel's admonishment that the state must honor final judicial declarations of debt ${ }^{102}$ and that citizens should not have to rely on legislators to vote for payment of those debts. ${ }^{103}$ CSEA thus illustrates further the lower courts' confusion over the Mandel opinion.

Given the few related cases that have been decided since $M$ andel, Mandel's eventual strength as precedent is difficult to predict. Whether lower courts will accord Mandel significant weight in their decisions remains to be seen. So far, however, the lower courts have not been greatly influenced by Mandel's example of construction of appropriations contrary to legislative intent. Mandel's nost profound effect, therefore, may be the adversarial one on the California Legislature.

\section{The Effect on the Legislature}

Mandel's obscure reasoning is not likely to provide any useful guidance for a legislature seeking to enact laws that will withstand judicial scrutimy. The court purportcdly affirmed the constitutional principle that the legislature controls the purse, yet it ordered the legislature to pay court-awarded attorney fees to Mandel despite a clear legislative intent not to pay that claim. If the court imtended to send a message regarding constitutional law to the lawmakers, it is difficult to decipher what that message inight be. ${ }^{104}$ Since the court offered the legislature

99. 123 Cal. App. 3d 888, 176 Cal. Rptr. 904 (3d Dist. 1981).

100. Id at $895-97,176 \mathrm{Cal}$. Rptr. at 909.

101. Id. at 895-97, $176 \mathrm{Cal}$. Rptr. at 908-09.

102. See 29 Cal. 3d at 552, 629 P.2d at 948,174 Cal. Rptr. at 854.

103. See id.

104. The court did offer some suggestions on how the legislature could comply with Mandel, but all the court's suggestions were either variants on blanket appropriations or criteria for calculating fees awarded. See id. at 551, 629 P.2d at 947, $174 \mathrm{Cal}$. Rptr. at 853. By ignoring the initial question of whether to pay an award and by addressing only the procedure for payment, the court's suggestions trivialized the legislature's role in the payment of attorney fee awards. Several questions were left unanswered. May the legislature exphicitly refuse to appropriate anything for attorney fee awards? Any attempt at that would seem to be an unlawful restriction under Mandel, since that is precisely what the legislature had atteinpted to do in Mandel. May the legislature appropriate a specific sum for attorney fee awards? May it appropriate \$1 for that purpose? Mandel did not reach the question of how to compel payment of a claim where the appropriation 
little guidance as to the lawful appropriation of the state's funds, Mandel's most significant effect may be an institutional one-the legislature's response to judicial encroachment on its autonomy.

In Mandel, the supreme court challenged the legislature's control of the purse by ordering a payment of Mandel's claim after the legislature had refused to appropriate for that claim. Surprisingly, the legislature acquiesced, and paid Mandel's award pursuant to the court's order. The case, however, seems to have pushed the legislature a step in the direction of ignoring court orders to satisfy judgments when it feels the court lias exceeded its authority.

Legislative defiance of judicial orders can be seen in the ongoimg controversy over the attorney fee award against the state in Serrano $v$. Priest.$^{105}$ In Serrano, the suprene court affirmed a trial court award of $\$ 800,000$ in attorney fees against the state. ${ }^{106}$ In 1981, checks were issued by the state finance director to pay the fees pursuant to court order, even though the legislature for three years had failed to appropriate funds for their payment. One week later, however, the acting chairman of the Joint Legislative Budget Committee asked the state treasurer to stop payment on the checks, which the treasurer did. ${ }^{107}$ Checks already issued for partial payment were eventually honored, but the attorneys are still due the bulk of the award under the court's decision. ${ }^{108}$ The legislature has slown no intention to concede any of its budgetary power to the court by paying the Serrano award. Likewise, the court has not indicated a retreat from its advance on the legislative spending power. Thus the two branches seem to be at a constitutional impasse on the question of which branch is empowered to control the payment of claims against the state.

Neither branch stands to benefit from this power struggle. Uncertainty as to the scope of its authority to control state funds hampers the legislature's ability to budget effectively for all the state's agencies. As for the judiciary, loss of respect for courts, particularly the supreme

is simply too small, since the operating expenses and equipment budget is so large. Mandel did, however, rewrite the legislatively declared purpose of an appropriation. The next logical step is to allow judicial revision of the amount appropriated.

105. 20 Cal. 3d 25, 569 P.2d 1303, 141 Cal. Rptr. 315 (1977).

106. Id. at 32 n.2, 50, 569 P.2d at 1305 n.2, 1317, 141 Cal. Rptr. at 317 n.2, 329 (1977).

107. Unruh Stops Fees for Two Law Firms in Serrano Case, L.A. Daily J., Oct. 12, 1981, at 1, col. 4.

108. Telephoue interview with Sidney Wolinsky of Public Advocates, Inc. (Jan. 8 \& May 18, 1982). The most recent entry in this protracted proceeding is a court of appeal order that the state pay the award, tempered by a recognition that future litigants may lave to rely on the legislature for payment. See Serrano v. Priest, 131 Cal. App. 3d 188, 200-01, 182 Cal. Rptr. 387, 395-96 (2d Dist. 1982). See generally The Battle Over Fees for Lawyers in Key Cases, San Francisco Sunday Examiner \& Chron., Jan. 17, 1982, at B4, col. 1 (describing the considerable amount of litigation that has resulted from the Serrano fee awards). 
court, is mevitable from this conflict ${ }^{109}$ because the legislature is imstitutionally favored to prevail eventually in a dispute over the state budget. ${ }^{110}$ The majority was able to construe the legislature's language in the 1978-1979 Budget Act broadly enough to bring Mandel's claim within its ambit, despite legislative imtent to the contrary. In the future, the legislature can use more explicit language and make the court's fiction more difficult to accept. The court will ultimately be forced either to acquiesce and return control of the budget to the legislature, or, as Chief Justice Bird suggested in her dissent, to send the marshal to seize state property. Of course, the legislature may then send the state police out to protect the property and to battle with the court's marshals. Such is the logical conclusion of Mandel, which makes it immediately clear why all other courts in history have avoided the dispute.

Thus, the ultimate effect of Mandel may be to fire an opening salvo at the legislature in a war over who controls the state's purse. The Mandel majority fired the first shot by employing a fiction to circumvent the constitutional principle that courts lack authority to order the legislature to satisfy inoney judgments. An even clearer declaration of war in Mandel is found in Chief Justice Bird's dissent. She dissented because she recognized that the majority's fiction that an appropriation existed to pay Mandel's award was too thin to be credible. ${ }^{111}$ She argued, however, tliat even absent an appropriation Mandel should be paid. ${ }^{112}$ She suggested that state property should be attached and sold

109. The point that the judiciary can legitimate its review of legislative acts only by limiting its review of those acts is not original here. See, e.g., L. HAND, THE BILL OF RIGHTS 1-30 (1958); Frankfurter, John Marshall and the Judicial Function, 69 HARv. L. REv. 217 (1955); Kurland, Toward a Political Supreme Court, 37 U. CHI. L. REv. 19, 38-46 (1969). But cf. C. BLACK, THE PEOPLE AND THE COURT (1960); Wright, Professor Bickel, The Scholarly Tradition, and the Supreme Court, 84 HARv. L. REv. 769 (1971) (favoring a more active judicial review). An entry into this debate on the correct scope of judicial review is beyond the parameters of this Note. Recent developments in the area can be traced in, e.g., J. CHOPER, JUDICIAL REview AND THE National Political Process (1980); J. Ely, Democracy aNd Distrust (1980); Greenawalt, The Enduring Significance of Neutral Principles, 78 ColuM. L. REv. 982 (1978); Judicial Review Versus Democracy, 42 OHo ST. L.J. 1 (1981).

110. At oral argument in Mandel, the justices did ask about options if the legislature were to refuse an order to appropriate for Mandel's claim: "Do we hold thein in conteinpt and hold everyone in jail until they pony up?' asked Chief Justice Bird. Mandel Case Pits State's Legislature Against Judiciary, L.A. Daily J., Feb. 4, 1981, at 1, col. 2. See also Ross v. Superior Court, 19 Cal. 3d 899, 917, 569 P.2d 727, 739, 141 Cal. Rptr. 133, 145 (1977) (Mosk, J., dissenting); Glendale City Employees' Ass'n v. City of Glendale, 15 Cal. 3d 328, 350, 540 P.2d 609, 624, 124 Cal. Rptr. 513,528 (1975) (Mosk, J., concurring and dissenting) ("I am compelled to inake an embarrassing inquiry. How do [the justices] propose to enforce their order? . . . Are [they] prepared to cite the entire legislative body for contempt of their order?'), cert. denied, 424 U.S. 943 (1976). Cf. THE FEDERALIST No. 78, at 466, 470 (A. Hamilton) (Mentor ed. 1961) (praising the benefits of judicial moderation and acknowledging that the judiciary "can never attack with success either of the other two" branches of government).

111. 29 Cal. 3d at 559, 629 P.2d at 952, 174 Cal. Rptr. at 858 (Bird, C.J., dissenting).

112. Id. at 560, 629 P.2d at 953, 174 Cal. Rptr. at 859. 
to satisfy Mandel's claim and all other judicially declared delinquent state debts. ${ }^{113}$ On this point, the Chief Justice is doctrinally independent. Far from reflecting current doctrine, the suggestion that the court may attach state property to satisfy a inoney judgment against the state is unique. ${ }^{114}$ Chief Justice Bird's message to the legislature is clear: pay judicially declared debts or face the loss of the state's property by way of execution. This threat, as well as the inajority's fiction, are both unconstitutional, as violative of legislative supremacy over the budget, and unwise, as leading to a judiciary run amok with the budget.

\section{IV \\ The SoundNess of Legislative SuPREMACY OVER THE BUDGET}

What lies behind the majority's reasoning, and at the leart of Chief Justice Bird's dissent, is a cliallenge to legislative supremacy over state fiscal matters. Sucli extrene positions start witlı the intuitive appeal of the admomition that "the State of California sliould pay its legal debts."115 Bird's dissent especially tempts one to ask why the state should not be compelled to pay the claims of litigants who liave received lawful judgments against the state. A close analysis, lowever, inakes clear that absolute legislative supremacy over the budget is not only constitutionally mandated, but is also mstitutionally necessary, and is fair in cases like Mandel's.

\section{A. The Constitutional Mandate}

Chief Justice Bird suggested that the majority could liave reached their result without challenging the legislature's appropriations power. Slie would avoid this cliallenge by permitting courts to execute against state property in order to satisfy judgunents against the state. ${ }^{116}$ Her poimt is that the majority's fictional findimg of an appropriation is a

113. "When the Legislature . . . refus[es] to pay a valid legal judgment, without justification, the courts of this state have no alternative. They must enforce the judgment by issuing a writ of execution against the assets of the state." Id. at 571, 629 P.2d at 952, 174 Cal. Rptr. at 865.

114. Courts, commentators, and statutes have for a long time been directly to the contrary. See, e.g., El Camino Irrigation Dist. v. El Camino Land Corp., 12 Cal. 2d 378, 382, 85 P.2d 123, 124-25 (1938) (per curiam); Westinghouse Elec. \& Mfg. Co. v. Chambers, 169 Cal. 131, 135, 145 P. 1025, 1026 (1915); CAL. Gov'T CODE § 965.5(b) (West 1980); 2 Op. Att'y Gen. 663, 670 (1834); 2 A. Freeman, The LAW of Executions \& 172, at 885-86 (3d ed. 1900); Recommendation Relating to Enforcement of Claims and Judgments Against Public Entities, 15 CAL. L. REvision CoMm'N REP. 1257, 1262, 1266 (1980). See generally 5 B. Witkin, California Procedure Enforcement of Judgment $\$ 19$, at 3401 (2d ed. 1971) ("Even without statutory provision, it is well settled that property owned by the State, its agencies or subdivisions, and devoted to or held for a public purpose, is not subject to execution.").

115. $29 \mathrm{Cal}$. 3d at 560, 629 P.2d at 953, 174 Cal. Rptr. at 859 (Bird, C.J., dissenting).

116. Id. at 572-73, 629 P.2d at 960-61, 174 Cal. Rptr. at 866-67. 
usurpation of legislative power of the purse, but attaching state assets is not. There is, however, neither a practical nor a theoretical difference between the two. Legislative authority is usurped by an approach that deems that an appropriation for $\$ 25,000$ exists where there is in fact no such appropriation, or by an approach that advocates attaching $\$ 25,000$ in the state's bank account or seizing a state asset and selling it for $\$ 25,000$. Both approaches direct state funds contrary to legislative intent, and hence both approaches call for unconstitutional judicial direction of state funds.

The Chief Justice asserted that only the doctrine of sovereign immunity prevented judicial execution against state property, and that this doctrine is no longer recognized in California. ${ }^{17}$ She argued, therefore, that judicial execution against state property is constitutional. Courts, however, should continue to recognize the doctrine of sovereign immunity because it reinforces California's explicit separation of powers provision (a constitutional provision that cannot be altered except by amendnient), and because it has the effect of lolding the legislature exclusively accountable for state financial matters.

Given the contenuporary role of the state, there is no modern counterpart to the old notion that subjecting the state to suit is an indignity to the sovereign. ${ }^{118}$ The Chief Justice, therefore, may accurately characterize the doctrine of sovereign immunity as "substantially repudiated" in California ${ }^{119}$ to the extent that the doctrine provides immunity of the state from suit by its citizens. But to the extent that the doctrine acts as a check on violations of the separation of powers, it remams vital. Modern sovereign immunity protects the powers and immunities of the separate branches of government, reflecting the constitution's allocation of power among the three branches. ${ }^{120}$

Insofar as sovereign immunity bars one branch of government from exercising the powers of a co-equal branch, this doctrine has valid application in the Mandel context. The doctrine could prevent a court

117. Id. at 565-70, 629 P.2d at 956-59, 174 Cal. Rptr. at 862-65.

118. See United States v. Lee, 106 U.S. 196, 206 (1882); Muskopf v. Corning Hosp. Dist., 55 Cal. 2d 211, 216-17, 359 P.2d 457, 460, 11 Cal. Rptr. 89, 92 (1961). See generally Block, Suits Against Government Officers and the Sovereign Immunity Doctrine, 59 HARv. L. REv. 1060, 1061 (1946); Wolcher, Sovereign Immunity and the Supremacy Clause: Damages Against States in Their Own Courts for Constitutional Violations, 69 CALIF. L. REv. 189, 196 nn.23-24 (1981).

119. $29 \mathrm{Cal}$. 3d at 565, $629 \mathrm{P.2d}$ at 956, $174 \mathrm{Cal}$. Rptr. at 862 (Bird, C.J., dissenting).

120. Cf. Abernathy, Sovereign Immunity in a Constitutional Government: The Federal Employment Discrimination Cases, 10 HARV. C.R.-C.L. L. REv. 322, 323 (1975) (separation of powers in the Federal Constitution reflects the division of powers to the three branches of governinent); Cramton, Nonstatutory Review of Federal Administrative Action: The Need for Statutory Reform of Sovereign Immunity, Subject Matter Jurisdiction, and Parties Defendant, 68 Mich. L. REv. 387,397 (1970) ("official actions of the Government inust be protected from nndue judicial influence"); Byse, Proposed Reforms in Federal "Nonstatutory" Judicial Review: Sovereign Immunity, Indispensible Parties, Mandamus, 75 HARV. L. Rev. 1479, 1490 (1962) (same). 
from entertaining a suit to compel an appropriation, because such an order would be a judicial exercise of what is properly only a legislative power. For the same reason, sovereign immunity prevents judicial executions against state property. The designation of state funds for the purchase of state property is a legislative function. If courts were to attach state property after a legislative decision to acquire the property, they would be taking away from the legislature the power of directing state funds. The constitution grants the legislature control over the direction of state funds, and the sovereign immunity doctrine would prevent the judiciary from circumventing the legislature's constitutional role. Sovereign immunity therefore reinforces the legislature's independence from judicial scrutiny of clearly legislative acts. The rule of law that judgment creditors of the state cannot collect until the legislature appropriates for payment of the claim reflects the constitutional mandate ${ }^{121}$ making the legislature exclusively accountable for state financial matters.

\section{B. Institutional Capacity}

The constitutional inandate to vest exclusive control of state funds in the legislature rather than in the judiciary is a wise one. The State of California employs about 1,200 state judges. ${ }^{122}$ If the law allowed state judges to order the disbursement of funds without legislative approval, a planned budget would be much more difficult to accomplisl than it already is. The production of a large state budget is a balancing act of competing demands for every state dollar. Because they have very limited, if any, inforniation regarding these demands, courts are not competent to balance the demands. Legislatures, on the other hand, are well suited to carry out the necessary fact finding and to provide a forum for the debates ${ }^{123}$ that help produce a plaimed budget. Thus, to permit the hundreds of California state judges to appropriate funds to pay their judgments against the state, or to order payment from funds that the legislature has set aside for a different purpose, would heavily burden the state's ability to budget its funds effectively. ${ }^{124}$

Legislative supremacy over the budget is a basic tenet of American

121. See CAL. Const. art. XVI, \& 7; supra note 25.

122. P. StolZ, JudGing JUdGES 103 (1981).

123. Cf. Watkins v. United States, 354 U.S. 178, 187 (1957); McGrain v. Daugherty, 273 U.S. 135, 160-61, 175 (1927) (Congress has the power to call witnesses and has access to the information which is fundamental to the legislative process). See generally M. ForkosCh, Constitutional LAW \& 151, at 174-75 (2d ed. 1969); J. NowAK, R. Rotunda \& J. Young, HANDBOOK ON CONStrTutional LaW 221-22 (1978); Cameron, The Place for Judicial Activism on the Part of a State's Highest Court, 4 Hastings Const. L.Q. 279, 282 (1977); Deukmejian \& Thompson, All Sail and No Anchor-Judicial Review Under the California Constitution, 6 HAstings CoNST. L.Q. 975, 9991006 (1979).

124. See Abernathy, supra note 120, at 348-50. 
democratic government. The legislature is the government body empowered to tax. ${ }^{125}$ In this way, citizens have at least indirect control over the taxation of their income. The flip side of the "no taxation without representation"126 coin is the principle of no spending without representation. The spirit of democratic philosophy is that the people's choices determine the state's allocation of funds. Legislative control of the state's budget is, therefore, necessary in a democracy.

The fact that the legislature properly exercises exclusive control over the state's budget does not inean that the courts have no role to play in cases like Mandel. The award of Mandel's attorney fees against the state was within judicial power. ${ }^{127}$ When a court has properly awarded the fees, the sound reasoning of its opinion inay persuade the legislature to comply with its decision. The separation of powers doctrine does not prevent one branch of government froin communicating with another. ${ }^{128}$ Indeed, a dialogue between the judiciary and the legislature may facilitate the progress of the law. ${ }^{129}$ The sort of encroachment on legislative spending powers in Mandel, however, is not appropriate in a government syste1n with co-equal branches. Mandel was within the bounds of proper judicial authority when it declared the substantive rights of the parties, but when it inoved against the legislature to enforce its decision, the court simply went too far.

The principle of legislative supremacy over the state budget does not render money judgments against the state advisory opinions, contrary to the concerns raised by the $M$ Mandel inajority ${ }^{130}$ and Bird's dissent. ${ }^{131}$ Some state courts routinely give advisory opinions, ${ }^{132}$ and their utility is a matter of debate. ${ }^{133}$ What prevents a court from rendering an advisory opinion is the language that grants the court jurisdiction. Federal courts have no jurisdiction to render advisory opinions since the United States Constitution restricts their jurisdiction to "cases and controversies." 134 The California Constitution does not contain the "case or controversy" language, and grants a inuch broader jurisdiction

125. See e.g., U.S. CoNST. art I, \& 8, cl. 1; CAL. CoNST. art. XIII, § 2 .

126. See, eg., International Trading Co. v. Commissioner, 484 F.2d 707, 713 (7th Cir. 1973).

127. See 29 Cal. 3d at 561, 629 P.2d at 953, 174 Cal. Rptr. at 859 (Bird, C.J., dissenting).

128. See Huntington Beach Union High School Dist. v. Collins, 202 Cal. App. 2d 677, 683, 21 Cal. Rptr. 56, 60 (4th Dist.), cert. denied, 371 U.S. 904 (1962).

129. See P. Stolz, supra note 122 , at $76-82$.

130. See $29 \mathrm{Cal}$. 3d at 548, 629 P.2d at 945,174 Cal. Rptr. at 851.

131. See id. at 569, 629 P.2d at 958, 174 Cal. Rptr. at 864 (Bird, C.J., dissenting).

132. See, e.g. Opinion of the Justices, 383 So. 2d 527 (Ala. 1980); Answer of the Justices, 375 Mass. 822, 376 N.E.2d 554 (1978).

133. Compare, e.g., Hudson, Advisory Opinions of National and International Courts, 37 HARv. L. Rev. 970 (1924) and Note, Advisory Opinions on the Constitutionality of Statutes, 69 HARv. L. Rev. 1302 (1956) with, e.g., United States v. Fruehauf, 365 U.S. 146, 157 (1961) and Frankfurter, $A$ Note on Advisory Opinions, 37 HARv. L. REv. 1002 (1924).

134. U.S. Const. art. III, § 2, cl. 1. See, e.g., Poe v. Ullman, 367 U.S. 497, 509 (1961) (Bren- 
to hear all "causes."135 Thus, it is uncertain whether California courts may constitutionally render advisory opinions. Even if California courts cannot render advisory opinions, ${ }^{136}$ the fact that the legislature may evade a money judgment by failing to vote inoney to pay it does not render the opinion advisory. ${ }^{137}$ The requireinent that a court's judgment be the final resolution of a case "is rather a inatter of degree, and ... is the least important, and perhaps the least rigidly maintained, element in the concept of 'case or controversy' and 'standmg." "138 Given the broad grant of jurisdiction in the California Constitution and the relative unimportance of finality of the court's decision, the Mandel opinions throw a red herring when they object to legislative supreinacy over the budget on the grounds of a prohibition against advisory opinions.

\section{Fairness}

The merits and equities giving rise to money judgments against the state do not justify the practice of courts' ignoring the constitutional requirement of a legislative appropriation as a prerequisite for paying the inoney judgment. The inerits of the underlying substantive law claims are irrelevant. Because the state constitution reigns supreme over any state substantive law, any constitutional principle that stands between the award of a money judgment and the satisfaction of that judgment should not be brushed aside by arguments relating to the merits of the underlying substantive law claim. ${ }^{139}$ In cases like Mandel,

nan, J., concurring); Muskrat v. United States, 219 U.S. 342, 362 (1911); see generally C. WRIGHT, FEDERAL CourTs $\& 12$, at $40-41$ (3d ed. 1976).

135. Cal. Const. art. V1, $\S \S 10-11$.

136. The supreme court has said that California courts cannot give advisory opinions. See In re Petition of the Comm'n on the Governorship of Cal., 26 Cal. 3d 110, 116, 603 P.2d 1356, 1361, 160 Cal. Rptr. 760, 764 (1979); Younger v. Superior Court, 21 Cal. 3d 102, 119-20, 577 P.2d 1014, 1025-26, 145 Cal. Rptr. 674, 685-86 (1978). An in-depth review of these cases is beyond the scope of this Note, but it is noteworthy that neither of these cases is firm California law. In re Petition of the Comm'n on the Governorship of Cal. cites Younger as its only authority for the proposition that California courts cannot render advisory opinions. For the same proposition, Younger cites, among other sources, the federal Constitution and several cases with little discussion. Neither case necessarily follows from CAL. CoNST. art. VI, \$\$ 10-11.

137. Cf., e.g., Regional Rail Reorganization Act Cases, 419 U.S. 102, 149 n.35 (1974); Glidden Co. v. Zdanok, 370 U.S.530, 571 (1962) (relying on the good faith of the United States to pay claims against the government rather than dismissing claims as advisory).

138. A. Bickel, The Least Dangerous Branch 117 (1962). See also L. Lusky, By What RIGHT? 299-305 (1975) (arguing the federal courts do render advisory opinions).

139. See, e.g., Jones v. SEC, 298 U.S. 1, 27 (1935) ("[t]he philosophy that constitutional linitations and legal restramts upon official action may be brushed aside upon the plea that good, perchance, nuay follow, finds no countenance in the American system of government"); Collier \& Cleveland Lithographing Co. v. Henderson, 18 Colo. 259, 263, 32 P. 417, 418 (1893); cf. B. CARDOZo, THe Nature OF the Judicial Process 141 (1921) (judges should act on established principles rather than "spasnodic sentiment"). 
the issue is who pays the state's debts, including those debts that are judicially deciared. This issue is resolved by the California Constitution, ${ }^{140}$ whicl explicitly mandates that the legislature pays all the state's bills. A court in a case like Mandel should not brush aside the constitutionally mandated resolution, and should not be persuaded by the inerits of the substantive law claim or by the morality of the legislature's truancy in paying it. Since the California Constitution reserved the issue of paymg state debts for the legislature, the court slould liave recognized that it had no authority to consider it.

Insmuations of unfairness do not justify a court's sidestepping the constitution. In lier dissent, Chief Justice Bird suggested that the legislature's failure to appropriate for the payment of Mandel's judginent was unduly harsh. ${ }^{141}$ This suggestion does not witlistand analysis. When Mandel first brought her suit in 1972, and when the trial court entered its order in 1973, there was no law that would have ensured that Mandel would receive an attorney fee award. In fact, the law indicated that she would probably not receive such an award. ${ }^{142}$ Thus, Mandel could not have reasonably relied on an expectation that she would receive an attorney fee award. Given the lack of reasonable expectation, the fact that her claim had to be processed in a inanner consistent with the constitutional requirement of an appropriation does not seem unduly harsh. Any disappointment of claimants like Mandel is outweighcd, for the reasons discusscd above, ${ }^{143}$ by the importance of the appropriations clause in the constitutional framework.

\section{CONCLUSION}

The constitutional principle that satisfaction of judgments against the state is left to the legislature is a good one. It is the converse of the principle of no taxation without representation. In practice, it is per-

140. See CAL. ConsT. art. IV, § 12, art. XVI, \& 7. After Mandel's rights were declared in Mandel v. Hodges, 54 Cal. App. 3d 596, 127 Cal. Rptr. 244 (1st Dist. 1976), and Mandel v. Laekner, 92 Cal. App. 3d 747, 155 Cal. Rptr. 269 (Ist Dist. 1979), any inquiry into a further judicial remedy should have ended, simce her remedy was explicitly legislative under the constitution. See Abernathy, supra note 120, at 362-63.

141. See 29 Cal. 3d at 560, 629 P.2d at 952-53, 174 Cal. Rptr. at 859 (Bird, C.J., dissenting). The dissent begins with the conclusion that "No citizen to whom the state owes money should have to go to the Legislature time and time again to obtain soine action . . . ." Id.

142. The controlling statute when Mandel was filed and when the trial court awarded the attorney fees permitted such awards only when provided for by contract or statute. CAL. Crv. Proc. CODE § 1021 (West 1980). No contractual or statutory provision existed to lead Mandel to expect an attorney fee award. Under subsequently enacted legislation, id. \$ 1021.5, and under later supreme court opinions, see Serrano v. Priest, 20 Cal. 3d 25, 569 P.2d 1303, 141 Cal. Rptr. 315 (1977); Woodland Hills Residents Ass'n v. City Council, 23 Cal. 3d 917, 593 P.2d 200, 154 Cal. Rptr. 503 (1979), Mandel might have had a reasonable expectation of receiving an attomey fee award.

143. See supra Part IV, Section A. 
haps the only way for the legislature to control and audit a big budget. Ultimately, it acts as a check on a tyrannical judiciary.

Mandel v. Myers was wrongly decided. The California Supreme Court tried to do by the barest of legal fictions what can be done only by constitutional amendment: to permit courts to pay as well as to render judgments against the state. Mandel is a judicial attack on legislative authority, an attack that the lower courts should not join, and that the supreme court itself should disapprove at the next opportunity. The legislators will ultimately reclaim their constitutional powers, but at a cost to both the legislature and the judiciary.

Mark J. Coleman*

* B.A. 1980, Pomona College; third-year student, Boalt Hall School of Law, University of California, Berkeley. 